UDC: [821.111Шекспір.09-057.4 + [378.022.096:82(100)=161.2]](477.83-

25)'’1915/1994'’М.С.Шаповалова(092)

\title{
МАРІЯ ШАПОВАЛОВА: ЖИТТЕВИЙ І ТВОРЧИЙ ШЛЯХ НАУКОВЦЯ
}

\author{
Ярема Кравець
}

\author{
Кандидат філологічних наук, доцент, \\ Кафедра світової літератури, \\ Львівський національний університет імені Івана Франка (УКРАЇНА), \\ 79000, м. Львів, вул. Університетська 1, \\ e-mail: yaremakravets@gmail.com
}

\section{РЕФЕРАТ}

У статті говориться про життєвий і творчий шлях Марії Семенівни Шаповалової (1915-1994), відомого літературознавця, багаторічного доцента кафедри світової літератури Львівського національного університету імені Івана Франка. Метою статті є висвітлення важливіших етапів діяльності педагога і науковця, який працював у галузі українського шекспірознавства, англійського красного письменства різних часів і періодів, англійського робітничого роману. Дослідницька методика. У статті використовується системний підхід із застосуванням історико-літературознавчого, генетичного та порівняльного методів. На основі цих методів з'ясовано внесок ученого в історію українського шекспірознавства, дослідження давньої і сучасної англійської літератури, опрацювання вагомих навчальних посібників і підручників 3 історії західноєвропейських літератур середніх віків та Відродження. Результати. У дослідженні подано майже півстолітній творчий шлях науковця, розповідь про задум і здійснення вартісної праці про входження В. Шекспіра в український літературний процес. Наукова новизна. Стаття є першою студією в українському літературознавстві про багатогранну діяльність доцента Марії Шаповалової, зокрема щодо опрацювання підручника 3 історії західноєвропейської літератури, який своїми трьома виданнями посьогодні залишається одним із найавторитетніших вузівських підручників. Практична вартість. Стаття може стати підгрунтям для зацікавленого прочитання наукової спадщини ученого-літературознавця, пізнання історії викладання світової літератури у Франковому виші.

Ключові слова: літературознавчі дослідження, англійська література, Марія Шаповалова, шекспірознавство, навчальні посібники та підручники.

\section{MARIYA SHAPOVALOVA: LIFE AND CREATIVE PATH OF THE SCHOLAR}

\author{
Yarema Kravets' \\ $\mathrm{Ph}$. D. of Philology, Assistant Professor, \\ Department of World Literatura, \\ Ivan Franko National University of Lviv (UKRAINE), \\ 79000, Lviv, 1, Universytetska str., \\ e-mail: yaremakravets@gmail.com
}

\section{ABSTRACT}

The article deals with the life and creative path of Mariya Semenivna Shapovalova (1915-1994), a famous literary critic, long-term Associate Professor at the Chair of World Literature, Ivan Franko National University of Lviv. The paper aims at covering the most important stages in the activity of the University lecturer and scholar who worked in the field of Ukrainian Shakespearean Studies, English belles-lettres of different times and periods, the English working-class novel. Research methodology. The article employs a systemic approach combined with applying the historical-and-literary, genetic-and-comparative methods, based on which a clarification is made as to the contribution of the scholar to the history of Ukrainian Shakespearean studies, research into ancient and modern English literature, elaboration of substantial teaching manuals and textbooks on 
the history of Western European literatures of the Middle Ages and the Renaissance epoch. Results. The research presents an almost fifty-year long creative path of the scholar, a narrative about the idea and implementation of the valuable work on the entry of W. Shakespeare into the Ukrainian literary process. Scholarly novelty. The article is a pioneering exploration in Ukrainian literary studies on the multifaceted activities of Associate Professor Mariya Shapovalova, in particular concerning the development of a textbook on the history of Western European literature, the three editions of which present up till now a most authoritative university textbook. Practical value. The article can become a basis for an interested reading into the scholarly heritage of the literary theorist, study on the history of teaching of world literature at the Ivan Franko National University of Lviv.

Key words: literary studies, English literature, Mariya Shapovalova, Shakespearean studies, textbooks and manuals.

У вірші «Маркіян Шашкевич» його автор Дмитро Павличко писав: «Я так як бачу Маркіяна. Я так як чую Маркіяна» [3, с. 68]. Використавши ретроспекцію із твору поета, розпочну наступними словами: «Як нині бачу Марію Семенівну Шаповалову такою, якою прийшла до нас, студентів другого курсу факультету іноземних мов набору 1961 року, на свою першу лекцію 3 «Історії зарубіжної літератури»: високого зросту, поставна, на вигляд строга, у темному одязі. Такою строгою сприймалася нами, студентами, - дисциплінованою, організованою, лаконічною, лекторкою чіткого структурованого навчального матеріалу, небагатослівною у побуті.

Марія Семенівна Шаповалова народилася 6 жовтня 1915 року у місті Костянтинівка Донецької області, як зазначила у своїй автобіографії , «y сім’ $і$ кадрового робітника металургійного заводу». Закінчивши фабрично-заводську семирічку, вступила до педагогічного технікуму іноземних мов м. Снакієве. 3 1934 року навчалася на літературному відділі філологічного факультету Харківського державного університету, а наступного року продовжила навчання на відділі русистики Київського державного університету: туди повністю перевели академічну групу Харківського університету (Такий перевід виглядає доволі загадковим. Чи це не було спричинене раптовим зменшенням викладацького складу словесників, філологів-україністів? Доречно, мабуть, згадати таку інформацію: «В одній із доповідей 1934 року нарком освіти В. Затонський тріумфально свідчив, що знищено 1649 українських науковців„націоналістів”, здебільшого фахівців з української мови та історії». Додамо, що сам В. Затонський був репресований комуністами у липні 1938 року). Там одружилися два майбутні філологи - Володимир Дмитрук і Марія Шаповалова, подарувавши згодом один одному трьох синів - Юрія (майбутнього фізика, художника-графіка знаного своїми виставками у теперішній картинній галереї імені Б. Возницького); Віктора (майбутнього філолога-літературознавця, відомого перекладача 3 англійської літератури, доцента кафедри світової літератури ЛНУ ім. Ів. Франка); Сергія (в майбутньому за фахом фізика). 1938 року Марія Шаповалова закінчила навчання і наказом наркома з освіти була призначена викладачем західноєвропейської літератури Запорізького державного педінституту, в якому вже з 1937 року працював ії̈ чоловік.

3 початком Другої світової війни на території колишнього союзу разом 3 колективом інституту перебувала в евакуації у місті Ленінабад (тепер Худжанд) Таджицької РСР, де працювала бібліотекарем; згодом - викладачем медшколи, а далі - до липня 1944 року викладачем англійської мови 
авіаспецшколи у м. Пенджікент. Того ж року повертається до Запорізького педінституту, а з вересня 1944 року призначена викладачем Львівського університету імені Івана Франка.

Марія Семенівна Шаповалова розпочала роботу викладачем кафедри історії західноєвропейської літератури (тепер - кафедра світової літератури) ЛДУ ім. Ів. Франка 1944 року, коли кафедра перебувала у складі філологічного факультету, нею завідував професор Михайло Рудницький (до 1947 року), а далі - літературознавці Климент Забарило і Василь Воробйов. На кафедрі ще не було професора Олексія Володимировича Чичеріна, який прибув до Львова 1947 року, став ऑiі доцентом, а вже незадовго, 1948 року - завідувачем. Не існувало факультету іноземних мов, окремої структурної одиниці з 1950 року. Кафедра поволі поповнювалася новими викладачами.

У своїй автобіографії М. С. Шаповалова зазначала, що 1947 року склала іспити кандидатського мінімуму, завершує роботу над кандидатською дисертацією. 1951 року захистила дисертацію і через два роки була затверджена доцентом кафедри. Керівником дисертації був авторитетний літературознавець, поет, перекладач Михайло Рудницький. Дисертантка захистила безперечно новаторську роботу, розпочавши нею свою дорогу понад чверть століття до монографії «Шекспір в українській літературі» (1976р.). Попри обов'язковий на той час ідеологічний підтекст дисертації дослідниця зосередила свою увагу на таких вузлових питаннях, як Шекспірівське франкознавство, індивідуалізація типових характерів, багатогранність і глибина розкриття психології, динамічність. Велику допомогу дисертантці своїми порадами надав академік Михайло Возняк.

Захистивши дисертацію, Марія Семенівна розширює коло літературознавчих зацікавлень, опрацьовуючи наукові проблеми, які стають визначальними для iii подальшої наукової роботи: українське шекспірознавство, англійське красне письменство різних часів і періодів, англійський робітничий роман. 3'являються статті «Іван Франко про німецьку літературу ХУІІІ ст.», «Філдінг як теоретик реалістичного роману», «Питання теорії роману в «Дон Кіхоті» Сервантеса». М. С. Шаповалова $є$ авторкою майже двадцяти статей про англомовних та американських письменників в окремих томах першого видання УРЕ: стаття «Література Великобританії», літературні портрети Томаса Гарді, Джерома Джерома, Драйдена, Вашингтона Ірвінга, Кіплінга, Ерскіна Колдуелла, Ленгленда, Мільтона та ін. Значна кількість письменників дістала своє трактування у наукових доповідях доцента, в її публікаціях на сторінках львівської періодики, у виступах на республіканських конференціях. Дуже часто такі виступи стосувалися ширших проблем, пов'язаних із шекспірознавством, наприклад, «Шекспірові міркування про мистецтво» (доповідь втілилася в окрему публікацію в Республіканському науковому збірнику 1964 року), «Шекспір в українських перекладах» (публікація того ж року). Науковець не цуралася і виступів перед ширшими колами непрофесійних слухачів, пропагуючи творчість англійського драматурга під гаслом «Шекспір близький усім часам». 
Читачам цього матеріалу цікаво дізнатися i про тісні контакти, що існували в певний час між кафедрою зарубіжних літератур і українським драматичним театром імені Марії Заньковецької надто, коли йшлося про сценічне прочитання окремих трагедій Шекспіра «Гамлет», «Король Лір», а також драм Г. Ібсена.Викладачі кафедри М. С. Шаповалова і Н. Х. Копистянська, старший лаборант Г. Л. Рубанова на чолі із професором О. В. Чичеріним були строгими і доброзичливими консультантами режисерів та акторів, брали участь у передпрем'єрних здачах вистав. Науковець була постійним дописувачем університетської багатотиражки «За радянську науку», в якій пропагувала творчість видатніших письменників світової літератури, розповідала про сценічне втілення окремих трагедій Шекспіра. Ось невеликий уривок із одного із звітів доцента М. С. Шаповалової: «Читала лекиї «Роман Роллан на Украӥні» (по телебаченню), «Гамлет» $i$ «Король Лір» Шекспіра, творчість Мольєра (на семінарах учителів)». А крім того, постійне рецензування на замовлення МВ ССО конкурсних наукових робіт, проектів посібників з історії зарубіжних літератур, журналу «Всесвіт» та ін. Науковець виступає із рецензіями на вагоміші видання українських літературознавців, друкуючи їх на сторінках українського наукового збірника «Іноземна філологія» (вип. 39, 42) - рецензії «Роман про робітничий клас в сучасній літературі капіталістичних країн», «Роберт Бернс на Україні» («Іноземна філологія», вип. 38).

Окремою сторінкою досліджень М. С. Шаповалової було вивчення сучасної англійської літератури, надто сучасного англійського роману, що особливо виявилося у 70-х рр., коли науковець вже дала українській культурі монографію «Шекспір в українській літературі». Зосереджує свою увагу на таких питаннях, як: «Морально-етичні проблеми в сучасному англійському романі»; «Сучасний англійський політичний роман»; «Епічні романні цикли в сучасній англійській літературі»; «Нові тенденції в англійському романі останніх років». Зацікавлення англійським робітничим романом датується у науковій діяльності М. С. Шаповалової ще 60-ми роками, коли науковець зазначала у своїх звітах про те, що продовжує дослідження теми «Англійський роман XX століття про робітничий клас». Саме в той час активно опрацьовує $\mathrm{i}$ окремі розділи монографії «Шекспір та українська література», виступає 3 доповідями «Максим Рильський - теоретик перекладу», «Радянська англістика за 50 років», «Високе і низьке в естетиці Шекспіра» тощо. І, як звичайно, в кожному своєму звіті додає: «Рещензувала наукові статті, брала участь в обговоренні статей викладачів та аспірантів, а також виступала опонентом із кандидатської дисертації». Серед рецензованих дисертацій бачимо особливо вагомі наукові дослідження - Фрідмана (1970), В. Данчева (1971) про Йоста ван ден Вондела, нідерландського поета і драматурга, засновника нідерландської національної драми.

До останніх років роботи на кафедрі доцент М. С. Шаповалова читала лекційний курс історії зарубіжних літератур Середніх віків та Відродження, XVII і XVIII ст., спецкурси англійською мовою «Англійський робітничий роман», «Сучасний англійський роман» для студентів 2 курсу англійської 
філології, провадила колоквіуми, керувала курсовими роботами, а з 1970 року увійшла до складу редколегії республіканського міжвідомчого збірника «Іноземна філологія», що наклало на неї додаткові обов'язки.

Особливою сторінкою в навчально-педагогічній роботі Марії Семенівни став посібник (а згодом - підручник) «Історія зарубіжної літератури. Середні віки та Відродження», що мав п'ять різних видань. Перший задум підручника зародився у формі методичного посібника 1967 року, пройшовши апробацію на заочному відділі факультету журналістики; 1973 р. він з'явився доповненим навчальним посібником накладом 10000 примірників, допущеним МВ CСO УРСР для студентів державних університетів. В анотації до посібника зазначалося, що в ньому враховані найновіші літературні праці з питань історії зарубіжних літератур зазначеного періоду. Загальну редакцію видання, що складалося 3 «Літератури середніх віків» (авторства Г. Л. Рубанової) та «Літератури доби Відродження» (авторства М. С. Шаповалової), здійснила М. С. Шаповалова.

Вже через дев'ять років виходить друком друге, перероблене і доповнене видання під загальною редакцією доктора філологічних наук професора О. В. Чичеріна. На відміну від попереднього, в ньому містилися нові розділи «Південнослов'янський героїчний епос» i «Слов'янські літератури доби Відродження» авторства знаного богеміста, доцента В. А. Моторного. Для більшої інтенсивності сприйняття й активізації самостійної роботи студентів у видання внесено ілюстрації, синхроністичні таблиці, контрольні питання, зразки тем курсових робіт та наукових доповідей. Навчальний посібник, призначений для студентів університету, виданий накладом 12 тис. примірників, обсягом майже 450 сторінок, приваблював гарним художнім оформленням недавно померлої художниці Вікторії Ковальчук [5]. Наступне перевидання посібника 1993 року з'явилося в іншому художньому оформленні 3 додатковим розділом «Приклади використання середньовічних і ренесансних сюжетів у творах мистецтва». 2011 року бачимо поки що останнє, перероблене і доповнене видання підручника (видавництво «Знання», м. Київ) 3 рекомендаційним листом Міністерства освіти і науки України - воно прийшло до студентів після вісімнадцятирічної перерви [6].

В одному із звітів початку 70-х рр. Марія Семенівна писала: «Працювала над докторською дисертацією «Шекспір в українській літературі». Завершено в остаточному варіанті глави «Шекспір в украӥнській літературі першої половини XIX ст.», «Шекспір у творчості окремих письменників: П. Куліша, П. Мирного, І. Франка, Лесі Українки, М. Рильського». Інші глави,визначені планом дисертації, написані в чорновому варіанті...». Багаторічне дослідження творчості Вільяма Шекспіра увінчалося монографією «Шекспір в українській літературі» [4], яка і досі є авторитетним дослідженням, не втративши своєї наукової вартості. Монографія, у якій вперше висвітлювалося як цілісний процес сприйняття Шекспіра видатними українськими письменниками XIX-XX століття, складається із трьох розділів, що відповідають хронологічним етапам сприйняття Шекспіра в Україні: Шекспір в українській літературі 30-60-х років XIX століття; Шекспір в українській літературі 70-90-х років XIX і початку XX 
століття; Шекспір в українській радянській літературі. Вагомість цього дослідження підтверджувалася переконливим списком використаної літератури - критичної, перекладами творів Шекспіра різних часів, англомовними працями про драматурга, залученням багатотомних лондонських шекспірівських видань. Зазначимо, що у списку використаної літератури подавалася 251 позиція (між іншим, лише одна позиція з цього великого списку була «ідеологічною» посиланням на твори К. Маркса і Ф. Енгельса). «Особливий інтерес викликає щзойно надрукована книга М. С. Шаповалової про Шекспіра та його роль в розвитку української літератури, - писав професор О. В. Чичерін у рецензії, що друкувалася на сторінках «Известий АН СССР. Серия литературы и языка», № 4 за 1977 р. - Книга М. С. Шаповалової яскраво, талановито $і$ переконливо знайомить читача з тим, як читали, як вивчали, як перекладали Шекспіра в Україні, як про нього дискутували, а найголовніше з тим, яке значення мала його спадщина для росту і розвитку української літератури» [див.: Додаток]. М. С. Шаповалова як авторитетний шекспірознавець стає членом всесоюзної Шекспірівської комісії, членом правління Української шекспірівської комісії, очолювала їі Львівське відділення.

Вийшовши 1984 року на пенсію, завершила викладацьку роботу, продовжуючи, однак, наукову діяльність як рецензент монографічних видань, окремих праць Інституту літератури ім. Т. Г. Шевченка НАН України, як-от п’ятитомне видання «Українська література в загальнослов'янському і світовому літературному контексті» (1987-1994), знаному як «вервесівський п’ятитомник». Недаремно у вступній довідці «Від редколегії тому» до т. 3 цього колективного дослідження, що з'явився друком 1988 р., читаємо: «Автори тому складають щиру подяку рецензентам <..> кандидату філологічних наук, доценту М. С. Шаповаловій <..> за циінні поради $i$ зауваження» [2, с. 6]. Доречно тут згадати ще одну репліку із щойно цитованої короткої довідкової передмови до цього тому: «Досліджуючи проблему взаємин української літератури з літературами Заходу і Сходу, автори ставили перед собою завдання підготувати грунт для створення синтетичної праці: зібрати і узагальнити матеріал стосовно контактних і генетичних зв'язків, визначити їхню роль і місце в історичному розвитку нашого письменства, по можливості зробити типологічні зіставлення на різних художніх рівнях (напрям, автор, твір), спираючись на методологічні розробки радянського $\mathrm{i}$ прогресивного світового порівняльного літературознавства» [2, с. 5]. Львівська науковець рецензувала два розділи т. 3 - «Українсько-англійські літературні взаємини» (авторка Р. П. Зорівчак) та «Українсько-бельгійські літературні взаємини» (автор Я. І. Кравець). Кваліфікована думка М. С. Шаповалової була особливо вартісна - сорок років викладання курсу «Історія світової літератури». Крім того, була авторкою особливо вартісної і потрібної для українського літературознавства монографії «Шекспір в українській літературі», що дістала авторитетну оцінку літературознавчої критики на сторінках журналу «Всесвіт», українського наукового збірника «Іноземна філологія», «Вопросов литературоведения» тощо. Вивчення всіх форм сприйняття шекспірівської спадщини в Україні через переклади, переробки, 
критичну інтерпретацію, творче засвоєння принципів шекспірівського мистецтва в оригінальних художніх творах, обробку образів і сюжетних мотивів, ремінісценції, образні аналогії були у цій монографії сімдесятих років провіщенням того літературознавчого методу дослідження, який потужніше виявить себе в українській літературній науці лише наприкінці 80-х рр. минулого століття. Значимість монографії М. С. Шаповалової була відзначена декількома цитуваннями у розділі про українсько-англійські літературні взаємини, згадкою про шекспірознавчі дослідження науковця поряд 3 такими знавцями перекладу, як Г. Кочур, М. Ажнюк, Р. Доценко та інші, розгорнутою характеристикою монографії на с. 126-127 цього розділу («У иій монографії вперше простежується $і$ висвітлюється сприйняття Шекспіра украӥнськими письменниками $X I X-X X$ ст. як иілісний процес») [7, с. 126-127], посиланням на статтю науковця «Шекспір у творчості Лесі Українки», («Слов’янське літературознавство і фольклористика», 1973 р., вип. 8).

Марія Семенівна Шаповалова відійшла із земного життя у листопаді 1994 року. 3 великою самопожертвою ця уродженка Донецького краю, розтерзаного нині нав'язаною війною, 3 таким розповсюдженим на Слобожанщині прізвищем своїх предків Шаповали, присвятилася дуже потрібним для української культури літературним проблемам, підтвердивши етнічну приналежність свого краю. Була осяяна двома велетами світового письменства - Франком і Шекспіром. Працювала і жила за Франковим гаслом: «...все $і$ всюди подати й свій голос у загальній справі, виявляти ту любов не потоками шумних фраз, а невтомною, тихою працею».

ДодАТок

РЕЦЕНЗІЯ О. В. ЧИЧЕРІНА НА КНИГУ М. С. ШАПОВАЛОВОЇ «ШЕКСПІР В УКРАЇНСЬКІЙ ЛІТЕРАТУРІ» (ЛЬВІВ: ВИЩА ШКОЛА, 1976. 212 с.)

История того, как великий иностранный писатель внедряется в жизнь того или другого народа, как он проходит через его литературу, какой оставляет в ней след, - это история, ведущая к очень глубокому пониманию характера международных культурных связей, пониманию этого автора, взятого в действии, в обнаружении творческой его энергии.

В советском литературоведении первый пример такого рода исследования - превосходная книга В. М. Жирмунского «Гете в русской литературе». Хочется отметить и весьма удачную книгу И. Катарското «Диккенс в России». Такого рода темы, посвященные роли русских и иностранных писателей в украинской культуре, характерны для украинского литературоведения.

Особенный интерес вызывает только что появившаяся книга М. С. Шаповаловой о Шекспире и его роли в развитии украинской литературы.

Поразительно, с какой настойчивостью многие украинские писатели в XIX в., и в наше время захвачены были одной мыслью: их родная литература должна достигнуть уровня творчества великого английского драматурга. Так Михаил Драгоманов в 70-х годах прошлого века мечтал о хороших переводах Шекспира на украинский язык и протестовал против переработок, упрощающих и принижающих великого драматурга, именно потому, что он верил в будущее своей родной литературы, которой нужны подлинные образцы, а не подделки. И Панас Мирный в то время, когда он жаждал творческого подъема «такой художественной силы, которая бы покоряла людей и делала бы их лучше» (с. 99), восхищался силою шекспировского слова, глубиной его мысли, ставил его своим современникам в пример и сам пытался переводить его.

М. С. Шаповалова показывает, что и в романах П. Мирного в концепции человеческих характеров сильно сказывается влияние Шекспира.

Иван Франко именно в работе над Шекспиром и переводами его трагедий создавал свою теорию перевода: переводчик должен в совершенстве знать оба языка, добиваться ясности и чистоты 
речи, не допускать украинизации, не утрачивать национального характера оригинала, сохранять особенности поэтической формы, сохранять тонкости стиля, избегая при этом рабского копирования переводимого текста. «Дословность попросту невозможна, если передавать не столько слова, сколько дух оригинала» (с. 116).

Как М. Драгоманов и П. Мирный, Леся Украинка тоже мечтала о том, чтобы ее современники или преемники стали бы «славянскими Шекспирами» (с. 146).

Для тех, кто жил и трудился в литературе на рубеже XIX и XX вв. и кто был озабочен ее судьбами, Шекспир был противоядием декадентской литературе. И в статьях писателей того времени, и в творчестве особенно Леси Украинки Шекспир сыграл очень значительную роль, его мощный и высокий реализм вытеснял влияние таких деятелей и теоретиков декадентства, как С. Пшибышевский (с. 146).

При изучении Шекспира в значительной мере формировалось украинское литературоведение. Иван Франко для своих статей о Шекспире привлекал и классические труды Гердера, Лессинга, Гете, и новейшие для того времени исследования Сидни Ли, Е. Даудена, А. Брандля, А. Брауна и др., использовал суждения Пушкина, Белинского, Чернышевского. В то же время Франко и самостоятельно мыслил о Шекспире и как поэт, как драматург учился у него.

Трогательны некоторые письма литераторов, отложивших собственные труды, чтобы усердно и долго работать над переводами произведений Шекспира на украинский язык. В ноябре 1882 г. М. Старицкий, посылая свой перевод «Гамлета», так писал М. Костомарову: «Признаюсь, хотелось бы услышать Ваше дорогое для меня и ценное суждение об этом деле - есть ли хоть что-то путное в моем труде или одни отбросы?» - «... чи путяща хоч трохи робота, чи покидька?» (с. 86). Оживленное обсуждение достоинств и недостатков переводов Федьковича, Мирного, Кулиша проходит через переписку многих литературных деятелей Украины. Горячим было стремление Старицкого и других писателей, бравшихся переводить Шекспира, расширить возможности украинского литературного языка, обнаружить его богатство и силу.

В полной мере той и другой цели достиг в наше время Максим Рыльский. В книге М. Шаповаловой показано, что Октябрьская революция, а потом и объединение Украины породили новый плодотворный этап в развитии украинской культуры и, в частности, в усвоении мировой культуры и в искусстве художественного перевода. Труды украинских литературоведов, занимавшихся Шекспиром, - А. И. Белецкого, С. И. Родзевича, А. П. Шамрая, Н. А. Модестовой и др. - сыграли значительную роль в развитии украинской филологии.

Для Максима Рыльского Шекспир стал его спутником с юних лет и до конца его жизни. Уже юношеская дружба его с М. П. Алексеевым была окрашена одинаковым их влечением к Шекспиру (с. 170).

Значение Шекспира в творчестве Рыльского, Бажана подробно рассмотрено в книге М. Шаповаловой. Дается тщательный анализ переводов. Приводятся убедительные слова Л. Первомайского: «...Рыльский не столько переводит в обычном значении этого слова, сколько творит украинские оригиналы произведений мировой позии... Его переводы обнаруживают безграничные возможности современного украинского поэтического языка...» (с. 183).

Книга М. С. Шаповаловой в живой, талантливой и убедительной форме знакомит читателя с тем, как читали, как изучали, как переводили Шекспира на Украине, как о нем спорили, а главным образом с тем, какое значение имело его наследие для роста и развития украинской литературы [1].

\section{ЛІТЕРАТУРА}

1. Чичерін О. Рец. на кн.: Шаповалова М.С.Шекспір в українській літературі. Олексій Чичерін. «Треба бачити і розуміти серием ...» (літературознавчі студіï). Львів : ЛНУ імені Івана Франка, 2018. С. 290-292.

2. Від редколегії тому.. Украӥнська література в загальнослов'янському $i$ світовому літературному контексті: в 5 т. Київ : Наук. думка, 1988. Т. 3 : У взаєминах з літературами Заходу і Сходу. С. 5-6.

3. Павличко Дм. Маркіян Шашкевич. Вінок Маркіянові Шашкевичу. Поезї, статті, виступи, хроніка. Київ : Рад. письменник, 1987. С. 68-69.

4. Шаповалова М. Шекспір в українській літературі. Львів : Вища шк., 1976. 212 с.

5. Шаповалова М., Рубанова Г., Моторний В. Історія зарубіжної літератури. Середні віки і Відродження : підручник. Львів : Вища шк., 1982. 440 с. 
6. Шаповалова М., Рубанова Г., Моторний В. Історія зарубіжної літератури. Середні віки та Відродження: підручник. 3-те вид., переробл. і доп. / за ред. Я. І. Кравця. Київ : Знання, 2011. $476 \mathrm{c}$.

7. Зорівчак Р. Українсько-англійські літературні взаємини. Украӥнськалітература в загальнослов'янському і світовому літературному контексті : в 5 т. Київ : Наук. думка, 1988. Т. 3 : У взаєминах з літературами Заходу і Сходу. С. 88-154.

\section{REFERENCES}

1. Chicherin, A. (2018), "Book review: Shapovalova, M.S. Shakespeare in Ukrainian Literature", Oleksiy Chycherin. "One should see and comprehend with the heart..." (literary studies) [Rets. na: Shapovalova M.S. Shekspir v ukrayins'kiy literaturi, Oleksiy Chycherin. "Treba bachyty i rozumity sertsem..." (literaturoznavchi studii)], LNU imeni Ivana Franka, Lviv, pp. 290-292. (in Russian).

2. (1988), "Note of the Editorial Board of the volume", Ukrainian Literature in the All-Slavic and World Literary Context in 5 vols. Vol. 3 ["Vid redkolehii tomu", Ukrainska literatura v zahalnoslovianskomu i svitovomu literaturnomu konteksti v 5 t. T. 3], Nauk. dumka, Kyiv, pp. 5-6. (in Ukrainian).

3. Pavlychko, Dm. (1987), "Markiyan Shashkevych", Wreath for Markiyan Shashkevych. Poetry, articles, speeches, chronicles, ["Markiian Shashkevych", Vinok Markiianovi Shashkevychu. Poezii, statti, vystupy, khronika], Radianskyi pysmennyk, Kyiv, pp. 68-69. (in Ukrainian).

4. Shapovalova, M. (1976), Shakespeare in Ukrainian literature [Shekspir v ukrainskii literaturi], Vyshcha shkola, Lviv, 212 p. (in Ukrainian).

5. Shapovalova, M., Rubanova, H. and Motornyi, V. (1982), History of foreign literature. The Middle Ages and the Renaissance: textbook [Istoriia zarubizhnoi literatury. Seredni viky i Vidrodzhennia : pidruchnyk], Vyshcha shkola, Lviv, 440 p. (in Ukrainian).

6. Shapovalova, M., Rubanova, H. and Motornyi, V. (2011), History of foreign literature. The Middle Ages and the Renaissance: textbook, 3rd edition, revised and brought up to date, edited by Yarema I. Kravets', Ya.I. [Istoriia zarubizhnoi literatury. Seredni viky ta Vidrodzhennia: pidruchnyk, 3-tie vyd., pererobl. i dop., za red. Ya.I. Kravtsia], Znannia, Kyiv, 476 p. (in Ukrainian).

7. Zorivchak, R. (1988), "Ukrainian-English literary relations", Ukrainian Literature in the All-Slavic and World Literary Context in 5 vols. Vol. 3. ["Ukrainsko-anhliiski literaturni vzaiemyny", Ukrainska literatura v zahalnoslovianskomu i svitovomu literaturnomu konteksti v 5 t. T. 3], Nauk. dumka, Kyiv, pp. 88-154. (in Ukrainian).

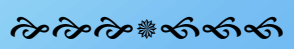

